\title{
Large shareholders and corporate governance outside the United States and United Kingdom
}

Praveen Kumar \& Alessandro Zattoni

The pioneering work of Berle and Means (1932) showed for the first time that US listed companies have their ownership rights dispersed among a large number of small investors since the early decades of the twentieth century. Building on this evidence, in the succeeding decades governance scholars have shown that the fragmentation of the ownership rights among a large number of small investors has some potentially negative consequences for the corporate governance of a firm. In particular, it creates the separation between ownership and control, i.e. control rights are delegated to top managers without ownership rights, which often provides little incentives for shareholders to monitor top managers because the monitor incurs all the costs while the benefits are distributed only proportionally according to the shareholder ownership (Hart, 1995).

Large shareholders can potentially address the free rider problem associated with costly managerial monitoring because their significant economic stake provides incentives to actively monitor top managers (Shleifer and Vishny, 1986). In addition, large shareholders may have sufficient voting power to see their interests represented through the proxy voting process (Shleifer and Vishny, 1997). In this view, then, large investors can act as an effective governance mechanism and contribute in solving the agency problem affecting large public companies (Hart, 1995). In order to reach their goals, large shareholders can develop different initiatives that may be classified as exit or voice. With the former option, dissatisfied investors decide to sell their shareholding in the firm in order to penalize poor management, while with the latter option they try to influence managers' decisions by communicating with managers and/or issuing shareholder resolutions (Chung and Talaulicar, 2010).

However, the majority of studies on large shareholders focus on firms operating in the U.S. and the UK; in particular, they emphasize the role of institutional investors as corporate watchdogs. The studies included in this issue significantly contribute to the literature in a variety of waysays. First, they contribute by developing a better understanding of the role of large investors both directly in shareholder meetings and indirectly through board representatives. Moreover, they explore these issues in two empirical contexts that differ significantly from the well-known Anglo-American milieu. As such, they contribute by developing a more fine-grained perspective on corporate governance; they go beyond traditional assumptions based on the Anglo-American contexts and take into account the relevance of specific national- and firm- level variables (Schiell, Ahmadjian and Filatotchev, 2014; Zattoni and Judge, 2012).

The first paper, a qualitative study by Buchanan, Chai and Deakin, explores hedge fund activism in Japan. The authors collected rich and deep knowledge on the topic through 43 interviews with 
representatives of several constituents (i.e. targeted companies, hedge funds, institutional investors, associations) during the 2007-13 time-period. Based on both interviews and the analysis of two specific case studies, the authors show that managers of large Japanese companies see themselves as responsible towards a wide set of stakeholders. In particular, the main stakeholders are shareholders, customers and employees. Interestingly, domestic institutional investors also share this view. The paper suggests that the dominant principal-agent model does not fit well in all institutional contexts. More specifically, Japanese firms have an internal orientation due to a limited role of the managerial labor market and of external directors, and an inside orientation of most investors. The results provide evidence against the inevitable convergence of corporate governance systems towards the primacy of shareholder governance.

The second paper, an empirical paper by Yeh, explores the emergence of shareholder activism promoted by institutional investors. In particular, the focus of the study is to investigate whether legally binding shareholder resolutions can incentive top managers to increase performance. The research setting is Japan, where large firms have been traditionally under the dominant influence of the main banks and where institutional investors have been largely absent or passive. Data are collected with regard to 135 Japanese firms that received shareholder proposals during the 200410 time-period. The results show that (i) firms receiving shareholders proposals have less insider ownership and are less efficient, (ii) the financial market reacts favorably to the announcement of proposals by large shareholders, and (iii) operating performance tends to improve in the postresolution year when proposals come from large sponsors. These findings seem to indicate that large shareholder activism can play a monitoring role in Japan and that corporate managers cannot ignore large shareholders.

The third paper, an empirical study by Bona-Sanchez, Perez-Aleman, Santana-Martin, investigates the impact of directors' political connections on the information content of earnings. The study starts from the premise that the effects of the political ties on firm's decisions and results, and so on the quality and credibility of accounting information, are highly relevant in European countries after the recent financial crisis. Authors collected data on an unbalanced sample of 112 Spanish non-financial listed companies during the 2003-11 time-period. The Spanish context is particularly appropriate as a large number of companies are politically connected, i.e. one board member has been in politics or had an office in the local government, and ownership concentration is high. The results of the study shows that the political connection affects negatively, and that the divergence of controlling shareholder' voting and cash-flow rights affects positively the informativeness of earnings. As such, the study emphasizes the relevance of several theories and suggests that regulators should encourage the disclosure of political connections by the board of directors.

The fourth paper, an empirical study by Pucheta-Martinez and Garcia-Meca, explores whether the presence of institutional investors' representatives on the board or in the audit committee can have an impact on financial reporting quality, measured as the probability that the firm receives a qualified audit report. Authors collected data on an unbalanced panel of 162 Spanish 
nonfinancial listed firms during 2004-10. The main results of the study show that institutional directors and institutional and non-independent directors sitting on the audit committee contribute positively to financial reporting quality. They also highlight that directors appointed to the board and to the audit committee by pressure-sensitive investors have a higher influence on financial reporting quality, and that this result is mostly due to savings banks' representatives on the board. These findings indicate that the background of the board of directors and their links with some large shareholders can affect their ability of the board to monitor management. Moreover, directors elected by different types of institutional investors do not have the same influence on the financial reporting quality.

\section{References}

Berle, A. and Means, G. 1932. The Modern Corporation and Private Property. New York: Macmillan.

Hart, O. 1995. Corporate governance: Some theory and implications, Economic Journal, 105: 678-689.

Chung, H. and Talaulicar T. 2010. Forms and effects of shareholder activism, Corporate Governance: An International Review, 18(4): 253-257.

Schiehll, E., Ahmadjian, C. and Filatotchev, I 2014. National Governance Bundles Perspective: Understanding the Diversity of Corporate Governance Practices at the Firm and Country Levels, Corporate Governance: An International Review, 22(3), 179-184.

Shleifer, A. and Vishny, R. 1986. Large shareholders and corporate control, Journal of Political Economy 94, 461-488.

Shleifer, A. and Vishny, R.W. 1997. A survey of corporate governance, Journal of Finance, LII (2): 737-783.

Zattoni, A. and Judge, W. 2012. Corporate governance and initial public offerings. An international perspective, Cambridge University Press, Cambridge, 2012. 